\title{
Growing Up Muslim: The Impact of Islamophobia on Children in a Canadian Community
}

\section{Siham Elkassem, MSW}

Vanier Children's Services, London, Ontario

\section{Rick Csiernik, PhD}

School of Social Work, King's University College, London, Ontario

\section{Andrew Mantulak, PhD}

School of Social Work, King's University College, London, Ontario

Gina Kayssi

Muslim Resource Centre for Social Support and Integration, London, Ontario

\section{Yasmine Hussain}

Muslim Resource Centre for Social Support and Integration, London, Ontario

Kathryn Lambert, MSW

Vanier Children's Services, London, Ontario

\section{Pamela Bailey MSW}

Vanier Children's Services, London, Ontario

\section{Asad Choudhary}

London Islamic School, London, Ontario

\section{Abstract}

With the increase of anti-Muslim bigotry in the current political and societal climate, ethnic minority children in western nations may experience increased nega- 
tive attention fueled by Islamophobia. Islamophobia is defined as the dislike of or prejudice against Islam, and individuals who are Muslims. A literature review yielded little research that examines the experience of Muslim children and their experiences with Islamophobia, particularly in the Canadian context. However, studies on the overall issue reveal Islamophobia is a phenomenon that has impacted Muslims around the world. This community-based study explored the dichotomous experiences of Muslim school-aged children who are taught theirs is a faith of peace and yet who regularly experience microaggressions and overt hostility because of their beliefs.

Keywords: Islam, Muslim, Islamophobia, bigotry, prejudice, discrimination, students, children

Experts claim that ethnic minorities who are thought of as being Muslim are experiencing increased negative attention fueled by Islamophobia (Council on American-Islamic Relations (CAIR), 2013; Lean, 2012; Poynting \& Perry, 2007). This claim has sadly been affirmed in Canada:

"6 dead, 8 injured in terrorist attack at Quebec City mosque" Montreal Gazette, January 30, 2017

"Enormous' spike in hate crime reports in Montreal since mosque attack" National Post February 1, 2017

"Liberal MP swamped by hate mail, threats over anti-Islamophobia motion in Commons"

The Star, February 16, 2017

"Anti-Islamic protesters demonstrate outside Toronto mosque calling for ban on Islam"

Global News, February 17, 2017

"Voters reject Quebec City-area Muslim cemetery project"

CTV News Montreal, July 16, 2017

These contemporary events indicate that despite outpourings of public support by many Canadians there is a distinct sense of Islamophobia, which is defined as the dislike of or prejudice against Islam, Muslims, and individuals especially as a political force (Oxford Dictionary, 2015) in Canada. Colleen Lundy, professor emeritus at Carleton University, wrote that during this overt systemic discrimination against Muslims, the social work profession in Canada has been ominously silent in the way they respond to clients who may be impacted by 
Islamophobia (2011). This is despite the fact that social workers are obligated to continuously challenge inequality, exploitation, and discrimination, and to reflect upon the impacts these injustices have on all clients (Canadian Association of Social Workers, 2016). Therefore, social work practitioners should be both professionally and morally concerned with the impact of Islamophobia on Muslim children and youth, and any victims of discrimination because of a "Muslim-like" appearance.

\section{Literature Review}

Currently, there exist few studies that look at the impact of Islamophobia on Muslim children (Arioan, 2012; CAIR-California, 2015) particularly within social work research ${ }^{1}$. The limited research that exists outside of social work suggests that Muslim children in public and non-Islamic private schools regularly encounter discrimination from school administrators, peers, and teachers (Arioan, 2012; CAIR-CAN, 2015; Maes, Stevens, \& Verkuyten, 2014).

\section{Islamophobia}

The contemporary definition of Islamophobia is connected with the concept of Orientalism, a term coined by the founder of Postcolonial Studies, Edward Said (Mason \& Poynting, 2007; Said, 1979). This word is defined as the association of Islam and Arabs with negative images, stereotypes, and sentiments (Said, 1979). The Council on American-Islamic Relations, a civil liberties and advocacy organization, views Islamophobia as a prejudice against or hatred of Islam and Muslims (CAIR, 2013). CAIR also describes an Islamophobe as an individual who holds a closed-minded view of Islam and promotes prejudice against or hatred of Muslims (2013). However, Islamophobia does not pertain to questioning Islam or Muslims about their faith or how they practice; it is not Islamophobic to denounce crimes committed by individual Muslims or those claiming Islam as a motivation for their actions (CAIR, 2013).

Since the beginning of the 21st century, there has been a disturbing rise of anti-Muslim sentiment in Europe, the United States, and Canada that has increased as hundreds of thousands of refugees flee the Syrian civil war. AntiMuslim prejudice was already significantly higher than the corresponding levels of anti-immigrant prejudice in Europe (Listhaug \& Strabac, 2007). A Time magazine poll released in August 2010 found 28\% of American voters did not believe Muslims should be eligible to sit on the United States Supreme Court,

1. A literature search was undertaken that included Google Scholar, Social Work Abstracts, SAGE, JSTOR, ProQuest using the following keywords: Islamophobia, anti-Muslim bigotry, Muslim, discrimination, school-aged children, and bullying. 
and nearly one-third believed that anyone who believes in Islam should be barred from running for President (Altman, 2010). A Canadian poll conducted by Angus Reid Public Opinion found that $68 \%$ of Quebecers, and $46 \%$ of the rest of Canada held an unfavorable opinion of Islam (Geddes, 2013).

Regular discourse of politicians, sensational news media coverage and entertainment helps to fuel discrimination, and provides a legitimate platform for anti-Muslim fear-mongering and Islamophobia. According to CAIR, Islam is the most oft-mentioned religion in news coverage, and a substantial portion of that coverage is negative (2016). According to a report issued by Gallup in 2009 , media coverage of Islam had a negative tone $40 \%$ of the time, and twothirds of the television coverage about Islam associates extremism with Muslims. Politicians in the United States and Canada use Islamophobic speech and legislation to advance their own agenda. During his campaigning, American President Donald Trump proposed a ban on Muslim migration, and then upon gaining the presidency twice attempted to implement an overt Muslim travel ban as one of his first executive orders. In Canada, MP Kelly Leitch championed the idea of screening immigrants and refugees on Canadian values, during her unsuccessful campaign to become leader of the Conservative Party. During an event unveiling measures of the Canadian government's new antiterrorism legislation Bill C-5, when asked how they would distinguish between youth who are radicalized and those who are just "messing around," former Canadian Prime Minister Steve Harper stated: "it doesn't matter what the age of the person is, or whether they're in a basement, or whether they're in a mosque or somewhere else," (Payton, 2015) reinforcing yet again the idea that anyone engaged in terrorism may be a person who attends a mosque or is a practicing Muslim.

Islamophobia can fuel the incidence of hate crimes against any person associated with Islam. Interestingly, victims of discrimination and hate crimes arising from Islamophobia are not just Muslims (Poynting \& Perry, 2007). Subjects of acts of prejudice and violence have been anyone who looked like they may be from somewhere in the "Middle East", or "looks Muslim." This could include dark-skinned, bearded men who wear turbans or women who have their hair wrapped. As a result of these factors, a number of the victims of antiMuslim violence have not been Muslim, but Sikhs and individuals of Indian, Lebanese Christian, and Greek descent (Poynting \& Perry, 2007). In one case in the United States, a Hindu temple was confused with a mosque and targeted by arson (Poynting \& Perry, 2007); in Hamilton, Ontario, a Sikh temple was burned down in response to the 9/11 attacks in the United States. In 2014, after the tragic killings of two Canadian soldiers at the hands of individuals linking themselves to violent extremism, there was an immediate increase in anti-Muslim incidents and hate crimes reported to the National Council of Canadian Muslims (NCCM, 2014). The NCCM received reports of 48 different 
hate crime incidents, as follows: 11 physical attacks on individuals or groups of individuals; 34 property attacks on Muslim institutions; and 3 threats against Muslim institutions (NCCM, 2014).

\section{Impact on Children}

Islamophobia has potentially even greater negative impact on Muslim schoolaged children, and the consequences of encountering discrimination in the public and at school are numerous and substantive (Arioan, 2012; CAIR-CA, 2015; Zinn, 2001). Mae and colleagues reported that in almost all cities across the world, children from immigrant groups are confronted with stigmatization, discrimination, and unfavorable images of their own group (2013). A study conducted in California involving 621 students enrolled in public and nonMuslim private schools found that these young people routinely faced verbal assaults, specifically those referencing bombs or calling American Muslim students terrorists. The study also reported that $55 \%$ of Muslim students had been bullied; $29 \%$ of hijab-wearing students experienced offensive touching or pulling of their hijab; and 19\% of the respondents report experiencing cyberbullying because of their religion (CAIR-CA, 2015). Studies report Islamophobia manifests at school in the form of teasing, bullying, name-calling, taunting, and physical assaults. Experts have identified Muslim girls as at risk for harassment by strangers because of headscarves or other identifiable clothing (CAIR-CA, 2015). The majority of the discriminatory incidents reported in these studies occurred in school settings, and are often perpetrated by students and, in some instances, teachers as well (Arioan, 2012; Maes, Stevens, \& Verkuyten, 2013).

In 2015, the world witnessed an extreme example of how Islamophobic stereotypes seeped into the school environment. In Irving, Texas, a 14-year-old American Muslim boy, Ahmed Muhammed, was arrested for bringing a homemade clock to school. Many believe because of his religion and race, school authorities assumed the project was a bomb and called law enforcement (Fantz, 2015). Exposure to this type of discrimination may leave children feeling marginalized and disempowered; this could lead to the internalization of negative stereotypes associated with Islam. Students who feel alienated from the school environment may suffer academically, have a low self-concept, and may fail to fully invest in their future (Aroian, 2012; CAIR-CA, 2015). Experts believe that sustained exposure to discrimination has effects that adversely impact mental and physical health and child development (Arioan, 2012).

Islamophobia is a phenomenon that has impacted Muslims around the world. It is a form of discrimination that has the potential to manifest into bullying and hate crimes among children in schools and adults in broader society. However, little is known in Canada of the lived experience of Muslim children and the impact that Islamophobia has had upon them. The goal of this explor- 
atory study is to begin to fill the gaps in the existing body of formal knowledge on this topic in order to build an informed response.

\section{Methodology}

\section{Procedure}

A letter of information outlining the study and its goals was sent home to the parents of all students in grades six, seven, and eight at a Muslim day school in southwestern Ontario; the letter invited their children to participate in a grade-specific focus group examining what it is like to grow up Muslim in the community. Students and their parents needed to consent in order to be considered for the study.

Focus groups consisting of students in grades six, seven, and eight were conducted at the Muslim day school after classes were concluded for the day. There were two facilitators in each focus group, at least one of which was a registered social worker with a graduate degree who belonged to the Ontario College of Social Workers and Social Service Workers. At least one member of the interview team was themselves also a self-identified Muslim. This protocol was established given the topic and the potential emotional responses that may have arisen during the focus group sessions. Students were asked eight openended questions (Appendix A).

\section{Population}

A total of 25 students participated in this study; twelve male and thirteen female students divided in the three age-oriented focus groups: six from grade six, nine from grade seven, and ten from grade eight.

\section{Data Collection and Analysis}

Focus group discussions were voice recorded and transcribed verbatim. Transcription software was not used based upon the assumption that that software may not pick up the potential cross-cultural language used by members of the population, particularly that related to Arabic and Islamic faith tradition terminology. Transcripts were reviewed for themes by the eight members of the research team, four researchers being Muslim, and then compared. Exemplars supporting each theme were used as a cross-reference mechanism. 


\section{Ethics}

Ethics approval was granted by the King's University College Research Ethics Review Committee.

\section{Results}

\section{The Disconnect: How We See Ourselves and Others See Us}

The most prominent theme that arose from the focus groups was the divide between how the Muslim youth saw themselves, their faith, and their community and how they viewed non-Muslims perceptions of themselves. Obviously, faith was of great importance to them and being Muslim gave them purpose, pride, and "something to hang on to" (7FV3). Participants indicated that being Muslim kept them out of harm, gave them a sense of compassion and provided guidelines for daily living. Among the most introspective comments was that being Muslim "provided a means to serve God and in this process to serve the community" (8MV3), for the traditional Muslim greeting is one that wishes peace and the mercy of God upon everyone, regardless of faith.

Comments made by these pre-teen and teenage participants reflected appreciation for the sense of respect and community in Islam:

I like the amount of respect in our religion... I feel like we show respect to ourselves and we show respect to others ... me and my friend were watching a movie and cashier was Muslim and we just said asalaamu-alkium (may the peace and blessings of God be upon you) and it just makes you feel united. (8FV4)

Not surprisingly, this was a media-savvy group and they were well aware of how media portrayed them:

The media makes it too hard on Muslims ... one small mistake and they make a huge deal. (6FV2)

I feel angered, to the point where I just turn off the TV and I'll walk away because I feel like there's nothing we can do anymore. (8FV4)

Also unsurprising were feelings of being continually judged: 
A lot of people are scared of us being different so they automatically assume that it's bad ... then they make it seem like we're weird . . . you don't drink? That's weird. Why don't you want to get drunk? (7FV3)

It's hard because you cannot give them a good picture of yourself because they already have their own picture that they got from the media. (8MV1)

Participants from each of the three grades discussed at length the double standards found in media portrayals and presentations of Muslims:

There are people from different races that have done so many bad things, yet nobody's going to go and say oh, you did this and then all of your race is bad, but one Muslim goes and does something and then they're like oh, this person did this now all Muslims are bad, I don't know, I may be wrong. Everybody's looking at me like I'm wrong or something (7FV1)

And every participant knew that those around them only thought of Muslims as terrorists:

They've portrayed as, in most media, as terrorists and people you have to stay away from. (7MV3)

We are portrayed as the villains of this world. (7FV3)

If you hear 'terrorist', you don't think of a Mexican or a Canadian, you automatically think of a Muslim. (7MV1)

The influence of the America's verbose president was also evident on Canadian grade-school-aged children, as comments included that "the president of the United States is against us" (8MV5), "he shows us so much hate" (8FV5), and "he just wants to make people believe that Muslims are not good at all" (7MV1). However, what was surprising was how this message already begins to be internalized at a young age:

... to be honest, when I think of a terrorist I think of an old Arab guy with a massive beard (7FV2).

This fear and negativity culminated in discussions examining Islamophobia. Despite all that being Muslim brings and what Islam represents and strives to embody among its adherents, the youth felt that many outside of their faith, outside their community, not only feared them but hated them, even though they were still only children. 
A lot of people are scared of ... or, like, they're afraid of us being different. So they would automatically assume that, you know, we're different, we're bad, we're not good people. (7FV3)

\section{Implications of the disconnect}

There was expression of fear by the youth in every focus group and why this is happening to them: "You feel unsafe because you are a Muslim" (8FV2). Entering into adolescence is a time of uncertainty regardless of who you are, but for this group there was the additional issue of fear of being who they are. This was discussed at several levels beginning with just trying to fit in:

We all went to a tournament and we had to go pray ... four or five of us found a spare room ... I heard a bunch of guys start coming up and I just remember being so scared ... like please don't do anything, please just leave. Please just leave. Please just leave. And afterwards I was like, why on earth was I so scared? (7FV2)

Or having to counter misbeliefs about Islam:

... "but aren't Muslims sexist?" . . "Aren't they transphobic," and "aren't they homophobic," and aren't they against this and that ... (7FV2)

and dealing with crucial peer-to-peer relationships:

I'm also afraid of being judged by people who are Muslim, because there are a couple controversial topics and I feel that people focus more on that than actually what's haram (forbidden). (8FV4)

What was most profound however were the microaggressions participants reporting occurred on a regular (if not daily) basis, that can lead to feelings of being overwhelmed and targeted:

I was at Victoria Park and then some guy came by and he started swearing at us ... and saying you guys are horrible, get out of here, you suck.(6FV5)

... we sat down somewhere and there were people there they would move away. (6FV3) 
In a basketball game when we beat them and we wear hijabs and one of the parents said well at least they didn't bomb us. (7FV3)

Once we were driving ... there was this one guy ... and he started screaming at us ... Muslims don't know how to drive, go back to your own country. (8MV2)

Whenever we're walking around, like me and my mom, you can see people's eyes on us ... just the dirty looks. (8FV4)

Microaggressions seem to be experienced more by young Muslim girls than boys, as they are more easily identifiable from afar if they wear hijab:

Wearing the hijab can be hard. People might bully you and make fun of you. Like what are you wearing? What is that piece of garbage on your head? (7FV1)

I get a lot of points and stares for my hijab during games . . they were pointing at me and laughing, pointing at my hijab. (7FV3).

However, there was also a serious impact on the Muslim boys in the groups who felt powerless to defend their mothers when they are harassed in public because of their appearance. This all contributes to an overall sense of powerlessness, which in turn made these young people feel that they are always on display. Thus, there is a sense that they must always be on their best behavior, as they have a greater accountability not only to themselves and their families but to their entire community and religion:

Around people we kind of, like, are obliged to be good and everything and set good examples because when a white person does something not that good they think okay . . . but then when a Muslim does something, they think, oh they're a terrorist. (8FV6)

People tend to judge negatively ... so when you're walking in the streets you have to try to be your best because if you do something wrong people will be like, oh, see, I told you Muslims are always terrible . . . people are watching you. They want you to do something wrong. (8MV3)

The focus groups occurred shortly after the February 2017 Quebec City mosque shooting, and this event crystallized the larger macro issues that impact Muslim youth: 
Now we're not allowed to pray in the mosque anymore, for our safety. (6FV2)

Our school's right beside a mosque. I was scared I didn't want to go to the mosque ... they killed so many people ... they were praying. (8MV4)

... it's just always in the back of your head ... am I going to pray peacefully and leave? Is something going to happen? Am I going to die? (8FV4)

\section{Resiliency and Hope}

However, being raised Muslim allows for resiliency in that there is a sense of belonging and community that pervades their lives as they begin to make the transition from childhood to adolescence:

There are a lot of Muslims in London, so wherever you go you kind of feel welcome, like even if you go to the randomest place ever and you just see, like a Muslim girl ... you just kind of smile. (8FV4)

I like our religion because most of the acts are toward making the world a better place. $(6 \mathrm{FV} 3)$

The youth also discussed themes of hope and provided examples of how those outside their community have reached out to them and their families spontaneously to show support, that they belong to a larger community and have supportive allies:

I play hockey and all my friends ... my teammates aren't Muslim but when they ask me what religion I am I tell them and then they're like, oh nice, and then I tell them we have fast and they're like, or really? And some of them try to fast a day ... so it makes me happy. Like they actually care and they don't take it from the media ... they actually believe that we're good. (6MV1)

After that day (Quebec City mosque shooting), lots of people in London, like from all ethnicities, they came out to the mosque ... some girl told me how she sympathizes with us and I just felt that was, like really nice. (8FV5)

They say behind every shadow there's light. The Quebec shooting may have seemed like a terrible event, you might find no good from it, but you could see that people sympathized for us after that. They were kinder to 
us. It shows us that there are still people who care. Not everything is dark. (8MV3).

\section{Discussion}

This exploratory study has confirmed what little is already known while gaining new insights with regards to the experience of Muslim children and the impact that Islamophobia has upon them in one Canadian community. The findings are consistent with the existing literature describing how Muslim school-aged children are living within their communities amid discrimination and stigmatization. Feedback from the participants support the literature related to the rise of Islamophobia, the impact of media including the 'Trump' effect, being victims of hateful comments in the community, and experiencing safety issues at school. Children were regularly subjected to oppression, and expressed fear due to being Muslim. Islamophobia is present in their daily living and has a direct impact upon them.

However, what the existing literature did not fully reflect was an appreciation of the multi-layered impact Muslim children currently face. The impact is felt in how the children saw themselves, their community, and particularly in the fears regarding their personal safety. This study revealed new insights around the disconnect between how Muslim youth see themselves, their faith, and their community and how they perceive non-Muslims' perceptions of themselves. We learned that these processes happen on several levels for these children, individually as they experience bullying and Islamophobia in their daily lives, but also in the witnessing of micro- and macroaggressions against friends and family. This is coupled with the umbrella Islamophobia that is commonplace in media that the children were already internalizing. Exposure to this type of discrimination left participants feeling marginalized and disempowered. Although this disconnect contributes to frustration for Muslim children, it also provides a space for reflection around how their faith is of great importance to them during and because of the turbulent times they live in. Their faith brings them peace despite the oppression they experience due to their beliefs. Many children described their religion as a source of pride and strength, providing them with a sense of respect and community along with a degree of resiliency and guidance on how to live in the world.

Analysis of the transcripts reflected some of the participants' awareness of a sense of being 'cautious' with non-Muslims, gauging whether they fell into a group that was sensitive to Muslim issues or those who outwardly were discriminatory. Participants discussed how media portrayed them negatively, and feelings of being continually judged and stereotyped. The children felt that despite all that being Muslim brings and what Islam represents and strives to 
embody among its adherents, that many outside of their faith, outside their community, not only feared them but hated them, even though they were still only children. How challenging this must be as one navigates work, social, and community relationships when you are never sure how you will be received and perceived.

There are distinct limitations with this study, as there are with any exploratory qualitative analysis. The study only involved children from one school in one community who were known to each other. Interviewers were not all Muslim, which may have impacted what was and was not shared during the focus groups. The sessions also took place soon after a major tragedy had befallen the Canadian Muslim community, and thus there was a greater heightened sense of being the other when the focus groups were held.

At risk of being too simplistic, much of what is experienced by Muslims from the non-Muslim community is the result of ignorance and lack of education. Time and again, ignorance has been shown to breed phobias and hate rather than acceptance, especially when individuals in positions of power and dominance are the ones perpetuating the ignorance and fear. In these instances, more of society tends to follow and is even emboldened in their actions. Thus, strategies for education need to happen at all levels of intervention, micro, mezzo, and macro. In addition, there needs to be a willingness and concerted effort to speak out against the discrimination at all levels of society, from the school environment to the larger political arena. The findings of this study can provide an impetus to bring the community at large to talk about the implications of the effects of Islamophobia on children and also give parents an opportunity to discuss the issues and the concerns they have for their children and themselves in the current environment of fear and hate.

On the micro level, school-aged children who are Muslim would benefit from opportunities to have ongoing conversations about their experiences outside of their family unit; some participants indicated reluctance to ask certain questions of family members or tell them of all that they experience on a regular basis. Teachers, school staff, and other caregivers would benefit from training related to how to support and respond to children when they face both critical incidents and daily microaggressions and discrimination they currently endure. At a community level, engaging in discussion about the impact Islamophobia has on school-aged children, and how to support this community is needed. The challenge for the Muslim community as a whole will be finding a way to bridge this disconnect and navigate the tension in a Canadian context; while there are many supporters and allies, there are communication obstacles in describing the realities of being subject to discrimination and negative stereotypes that have an ongoing effect upon their children. 


\section{References}

Altman, A. (2010). TIME poll: Majority oppose mosque, many distrust Muslims. Retrieved from: http://www.time.com/time/nation/article/0, 8599(2011799), 00.

Aroian, K. J. (2012). Discrimination against Muslim American adolescents. The Journal of School Nursing, 28(3), 206-213. https://doi.org/10.1177/1059840511432316

Barbera, R. A. (2008). Relationships and the research process: Participatory action research and social work. Journal of progressive human services, 19(2), 140-159. https://doi.org/10.1080/10428230802475448

Bayrakli, E \& Hafez, F. (2015). European Islamophobia Report. SETA/Foundation for Political, Economic and Social Research. Retrieved from: http://www.islamophobiaeurope.com/ reports/2015/en/EIR_2015.pdf

CAIR California (2015) MISLABELED: The Impact of School Bullying and Discrimination on California Muslim Students. Retrieved from: https://ca.cair.com/sfba/ wp-content/uploads/ 2015/10/CAIR-CA-2015-Bullying-Report-Web.pdf

Diamond, J. (2015). Cable News Network (CNN). Donald Trump: Ban all Muslim travel to U.S. Published Dec. 8, 2015. Retrieved from: http://www.cnn.com/2015/12/07/ politics/donald- trump-muslim-ban-immigration/

DiCicco-Bloom, B., \& Crabtree, B. F. (2006). The qualitative research interview. Medical education, 40(4), 314-321. https://doi.org/10.1111/j.1365-2929.2006.02418.x

Esposito, J. L., \& Mogahed, D. (2007). Who speaks for Islam? What a billion Muslims really think. New York: Simon and Schuster.

Every, D., \& Perry, R. (2014). The relationship between perceived religious discrimination and self-esteem for Muslim Australians. Australian Journal of Psychology, 66(4), 241-248. https://doi.org/10.1111/ajpy.12067

Fantz, A., Almasy, S \& Stapleton, A. (2015). Cable News Network (CNN). Teen Ahmed Mohamed brings clock to school, gets arrested. September 16, 2015. Retrieved from: http://www.cnn.com/2015/09/16/us/texas-student-ahmed-muslim-clockbomb/

Gallup (2010). Islamophobia: Understanding Anti-Muslim Sentiment in the West. Retrieved from: http://www.gallup.com/poll/157082/islamophobia-understandinganti-muslim-sentiment-west.aspx

Geddes, J. (2013) Canadian anti-Muslim sentiment is rising, disturbing new poll reveals. Retrieved from: http://www.macleans.ca/politics/ land-of-intolerance/

Global News. (2017). Anti-Islamic' protesters demonstrate outside Toronto mosque calling for ban on Islam. Retrieved from: http://globalnews.ca/news/3257296/ anti-islamic-protesters-demonstrate-outside-toronto-mosque-calling-for-banon-islam/

Lean, N. (2012). The Islamophobia industry: How the right manufactures fear of Muslims. London: Pluto Press.

London Census Fact Sheet. (2011) Retrieved from: https://www.london.ca/AboutLondon/ community-statistics/population-characteristics/Documents/4-\%20ethnoculturalJune21.pdf

Maier, H. W. (Ed.). (1969). Three Theories of Child Development: The Contributions of Erik H. Erikson, Jean Piaget and Robert R. Sears, and Their Applications. New York: Harper \& Row.

Maes, M., Stevens, G., \& Verkuyten, M. (2014). Perceived ethnic discrimination and problem behaviours in muslim immigrant early adolescents: Moderating effects of 
ethnic, religious, and national group identification. The Journal of Early Adolescence, 34(7), 940-966. https://doi.org/10.1177/0272431613514629

Montreal Gazette. (2017). 6 dead, 8 injured in terrorist attack at Quebec City mosque. Retrieved from: http://montrealgazette.com/news/quebec/4-reported-dead-inshooting-at-quebec-city-mosque

National Council of Canadian Muslims. (2013) National Security and Radicalization. Retrieved from: http://www.nccm.ca/wp-content/uploads/2014/03/NCCMPosition-Brief-National- Security-Radicalization.pdf

National Council of Canadian Muslims. (2014) ODIHR Hate Crime Report. Retrieved from: http:// www.nccm.ca/wp-content/uploads/2015/11/Hate-Crime-Report2014-National-Council- of-Canadian-Muslims.pdf

National Post. (2017). Enormous' spike in hate crime reports in Montreal since mosque attack Retrieved from http://news.nationalpost.com/news/canada/ montreal-man-accused-of-uttering-threats-and-inciting-hatred

Ontario Human Rights Commission. (2012) Discrimination experienced by Muslims in Ontario. Retrieved from: http://www.ohrc.on.ca/en/creed-freedom-religionand-human-rights-special-issue-diversity-magazine-volume-93-summer-2012/ discrimination-experienced-muslims-ontario.

Oxford Dictionary. (2015). Islamaphobia. Oxford: Oxford University Press.

Pyles, L. (2014). Theories and ideas for progressive organizer. In L. Pyles (Ed.), Progressive community organizing: Reflective practice in a globalizing world (second ed.) (pp. 34-52). New York: Taylor \& Francis Group.

Payton, L. (2015). The Canadian Broadcasting Company (CBC). Muslim groups 'troubled' by Stephen Harper's mosque remark. Retrieved from : http://www. cbc.ca/news/politics/muslim-groups-troubled-by-stephen-harper-s-mosqueremark-1.2940488

Pew Research Centre (2009). Mapping the Global Muslim Population: A report on the size and distribution of the world's Muslim population. The Pew Forum on Religious and Public Life. Retrieved from: http://www.pewforum.org/files/2009/10/ Muslimpopulation.pdf

Poynting, S., \& Perry, B. (2007). Climates of hate: Media and state inspired victimization of Muslims in Canada and Australia since 9/11. Current Issues in Criminal Justice, 19(2), 150-171.

Said, E. (1979). Orientalism. 1978. New York: Vintage, 1994.

Said, E. (2008). Covering Islam: How the media and the experts determine how we see the rest of the world (Fully revised edition). Random House.

Strabac, Z., \& Listhaug, O. (2008). Anti-Muslim prejudice in Europe: A multilevel analysis of survey data from 30 countries. Social Science Research, 37(1), 268-286. https://doi.org/10.1016/j.ssresearch.2007.02.004

Strauss, A., \& Corbin, J. (1994). Grounded theory methodology. Handbook of qualitative research, 273-285.

The Star. (2017). Liberal MP swamped by hate mail, threats over anti-Islamophobia motion in Commons. Retrieved from: https://www.thestar.com/news/ canada/2017/02/16/liberal-mp-swamped-by-hate-mail-threats-over-antiislamophobia-motion-in-commons.html

Walker, D., \& Myrick, F. (2006). Grounded theory: An exploration of process and procedure. Qualitative health research, 16(4), 547-559. https://doi. org/10.1177/1049732305285972 
Zinn, J. (2001). Muslim youth in Canadian schools: Education and the politics of religious identity. Anthropology and Education Quarterly, 32(4), 399-423. https://doi. org/10.1525/aeq.2001.32.4.399

\section{Appendix A: Youth Instrument}

What do you like about being Muslim?

What do you dislike about being Muslim?

Have you ever been treated differently because you are Muslim compared to non-Muslims you know?

How do you see Muslims in the media?

How do images of how Muslims are shown impact you?

Have there been any incidents that you witnessed or heard of that have made you feel unsafe because you are Muslim?

When I say "Islamophobia" what does it mean to you?

Is there anything else that you would like to talk about on this subject that I haven't asked you? 